\title{
IAMJ
}

INTERNATIONAL

AYURVEDIC

MEDICAL JOURNAL

ISSN: 23205091

[ब] (2)

Case Report

Impact Factor: 5.344

\section{AYURVED APPROACH TO DIMINISHING OVARIAN RESERVE (DOR) IN FEMALE INFERTILITY - CASE STUDY}

\author{
Divya Pawar ${ }^{1}$, Sameer Gholap ${ }^{2}$ \\ ${ }^{1}$ Post Graduate Scholar, ${ }^{2}$ Associate Professor and Guide; \\ Department of Prasuti Tantra Avum Striroga, SMBT College and Hospital, Nandi Hills, Dhamangaon, Igatpuri, \\ Nashik, Maharashtra, India
}

Corresponding Author: divi.pawar94@,gmail.com

\section{https://doi.org/10.46607/iamj4408082020}

(Published online: August 2020)

Open Access

(C) International Ayurvedic Medical Journal, India 2020

Article Received: 14/07/2020 - Peer Reviewed: 03/08/2020 - Accepted for Publication: 04/08/2020

(D) Check for updates

\begin{abstract}
According to Ayurveda Having no Baby is described as Vandhyatva and Infertility in Modern science. Infertility is a main issue in today's era. Many couples go for IVF, Surrogacy and many more with very little benefits. Nearly $10-14 \%$ of individuals are belonging to the reproductive age group are affected by Infertility. Infertility caused by Diminished Ovarian Reserve (DOR) results from an endocrinological imbalance. The rise in follicle stimulating hormone (FSH), decrease in Anti Mullerian hormone (AMH) and Antral follicle count (AFC) etc. for women age more than 35 years can lower pregnancy rates to less than $5 \%$ and increases miscarriage rates to more than $75 \%$. Ayurveda explained wide range of protocols and medicines for the management of Vandhyatva. In Ayurveda its appropriate correlation can be done with Dhatukshaya Vandhya explained in Harita Samhita. Ayurveda states four factors are mentioned Rutu, Kshetra, Ambu, Beeja should be in proper state in order to achieve conception and complete the pregnancy successfully.

Aim \& Objectives: To evaluate the efficacy of Shamana Aushadhi, Yog Basti, Uttarbasti in the management of Diminishing Ovarian Reserve (DOR) induced Female Infertility.

Materials \& Methods: It is the single arm, open labelled case study of the subject of 35 yrs age with primary infertility of Diminishing Ovarian Reserve (DOR) from Ayurveda College who has been treated with Shodhana Chikitsa as Yog Basti, Uttarbasti and Shamana Chikitsa simultaneously.
\end{abstract}


Results \& Discussion: There was improvement in hormonal assay with increase in Anti Mullerian hormone (AMH) and Antral follicle count (AFC) followed by conception later on. The Patient delivered with full term normal healthy female baby. Samshodhana and Shamana Aushadha helped to pacify Vata Dosha by Dhatukshaya Vandhya Chikitsa thus restored the fertility.

Conclusion: The selected treatment protocol i.e. Samshodhana and Shamana Aushadha is very effective in the management of Diminishing Ovarian Reserve (DOR) induced Female Infertility.

Keywords: Diminishing Ovarian Reserve (DOR), Dhatukshaya Vandhya, Yog Basti, Uttarabasti, Shamana Aushadhi etc.

\section{INTRODUCTION}

Infertility is a condition in women's life which indicates inability to procreate. Infertility is generally defined as one year of unprotected intercourse without conception. Sub-infertility is described as Women or Couples who are not sterile but exhibit decreased reproductive efficiency ${ }^{[1]}$ Decreased ovarian reserve (DOR) refers to the size of the non-growing or resting primordial follicle population which presumably determines the number of growing follicles and the quality which presumably determines the number of growing follicles and the quality or the reproductive potential of their oocyte. The oocyte related decline in fertility is known as "Decreased ovarian reserve (DOR)" ${ }^{[2]}$ Conception depends on the fertility potential of both the Female and Male partner. The major cause in Infertility is Female factor which is $40-55 \%{ }^{[2]}$. Female factors are Ovarian, Tubal, Cervical, Uterine and Endometrial factors (FIGO). Many factors are responsible for Female
Infertility which are Tubal Factors about $40 \%{ }^{[3]}$, Ovarian factor $0.5 \%$, Cervical factor $20 \%$ And Uterine factor $10 \%$. Also $30-40 \%$ in female ${ }^{[4]}$ and $10-30 \%$ in male are the causative factors seen. According to Shabdakalpataru a woman who has hindrance of any kind in normal process of conception is termed as Vandhya. For healthy progeny Pumbeeja (Shukra) and Streebeeja (Artava) are important ${ }^{[5]}$ Artavakshaya, Artavanasha are due to Dhatukshaya and Avarana in Artavavaha Srotasa ${ }^{[6]}$.

Diminishing Ovarian Reserve (DOR)- Diminishing Ovarian Reserve (DOR) is a condition in which the ovary loses its normal reproductive potential compromising fertility and causing early menopause. It comes out with reduction of oocyte quantity, quality and reproductive potential ${ }^{[7]}$. According to Ayurveda it is correlated with Dhatukshaya Vandhya explained in Harita Samhita ${ }^{[8]}$.

\section{Causes -}

\begin{tabular}{|l|l|}
\hline Autoimmune & Organ, non - organ specific auto antibodies bind gonadotrophins and receptors \\
\hline Iatrogenic & Chemotherapy, Uterine artery embolization, Ovarian drilling \\
\hline Infection & Varicella, Tuberculosis shigellosis, Malaria, Cytomegalovirus \\
\hline Oxidative stress & ROS induced DNA damage, Chromosomal abnormalities, Poor oocyte quality \\
\hline Environmental toxins & Tobacco, Polycyclic aromatic hydrocarbons \\
\hline Autosomal genes & FSH, LH, Oestrogen receptor mutation, CYP19A1 mutation etc \\
\hline Chromosomal defects & Monosomy, Turner Syndrome, Trisomy, Fragile X syndrome \\
\hline
\end{tabular}

Pathogenesis - The exacts pathology is obscure but it can be due to, Decrease in Primordial follicle pool, Accelerated atresia of follicles, Defective maturation, Recruitment of Primordial follicle
Clinical Features - primary / secondary infertility, menstrual irregularities, osteoporotic changes. Vaginal dryness thus dyspareunia, hot flushes, sleep disturbance, mood swings, weight gain, uterine prolapse etc. 
Ovarian Reserve Test -

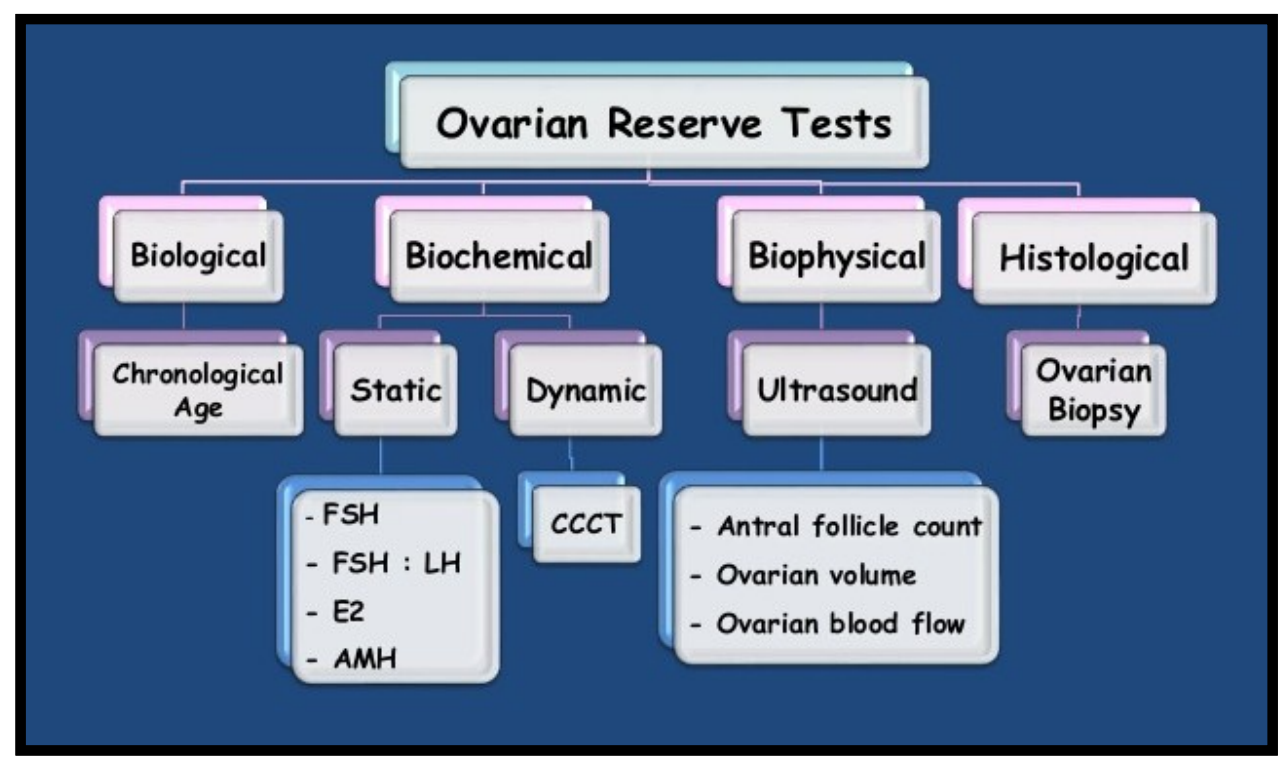

\section{Assessment -}

1) $\mathrm{AMH}<1.5 \mathrm{ng} / \mathrm{dl}$

2) Basal FSH between $>10-15 \mathrm{IU} / \mathrm{L}$ (on $3^{\text {rd }}$ day)

3) $\mathrm{AFC}<10$ Bilateral ovaries

\section{Case Report -}

Name - Xyz, Age - 35 Yrs., Occupation - IT Job, Socioeconomic Status - Middle, Chief complaint - Unable to conceive, Present Menstrual History (Since 1 \& $1 / 2$ year) LMP - 2/6/2018, 2- 3 days / 30 - 40 days, 1 pad / day, Irregular, Scanty flow , No dysmenorrhoea

Past Menstrual History (Before 1 \& $1 / 2$ year) - 4- 5 days / 28 - 30 days, 2 - 3 pad / day, Regular, Moderate flow, No dysmenorrhoea

Obstetric History - Married for 5 years, Score $=\mathrm{G} 1$ P0 A1 D0, A1 - 1-month spontaneous abortion (April 2017)

\section{General Examination}

Pulse - 76/min, Blood pressure - 126/82 mmHg, Respiration rate $-20 / \mathrm{min}$, Height $-160 \mathrm{~cm}$, Weight $-62 \mathrm{~kg}$, BMI - 24.22 (Normal), Temperature - 98.6, Body Build -Average, No Pallor, No Oedema Systemic Examination

RS / CVS / CNS - Normal, Per Abdomen - Soft, Nontender, L0 S0 K0, Per Speculum- Cervix - Parous, Normal size, No Nebothian cyst / polyp / erosion / fibroid, Vagina Healthy, No Bleeding, No Discharge Per Vagina- Cervix - at the level of ischial spine, Uterus - Normal size, AVAF, Non mobile, Bilateral fornices - free, non-tender, No palpable adnexal mas / ovaries, Cervical motion - free, non-tender

Table 1: Investigation - $(21 / 1 / 2018)$

\begin{tabular}{|l|l|l|l|}
\hline $\mathrm{Hb}$ & $11.8 \mathrm{gm} / \mathrm{dl}$ & $\mathrm{T} 3$ & $91.13 \mathrm{ng} / \mathrm{dl}$ \\
\hline TLC & $9,600 / \mathrm{cumm}$ & $\mathrm{T} 4$ & $7.34 \mathrm{ng} / \mathrm{dl}$ \\
\hline RBC & $4.01 \mathrm{Mill} / \mathrm{uL}$ & HIV/VDRL/HBsAg & Non - Reactive \\
\hline ESR & $22 \mathrm{~mm} \mathrm{in} 1 \mathrm{hr}$ & Montoux test & $2 \times 2 \mathrm{~mm}(\mathrm{~N})$ \\
\hline PLT & $2,77,000 / \mathrm{cumm}$ & LA & $31.51 \mathrm{~N})$ \\
\hline Blood group & $\mathrm{A}+\mathrm{ve}$ & ACL & $4.2(\mathrm{~N})$ \\
\hline FBS & $98 \mathrm{mg} / \mathrm{dl}$ & Urine Pus cells, Epi cells & Nil, $1-2 / \mathrm{hpf}$ \\
\hline Sr TSH & $4.02 \mathrm{Ulu} / \mathrm{ml}$ & --- & -- \\
\hline
\end{tabular}




\section{USG (TVS) on (4/6/2018)}

Uterus - AV measuring $6.8 \times 3.4 \times 4.6 \mathrm{~cm}$, endometrial thickness $-5 \mathrm{~mm}$, Ovaries and tubes are normal LMP - 2/6/2018, DAY 3, FSH -15.2 mlU/ml, AMH -.8 $\mathrm{ng} / \mathrm{ml}, \mathrm{AFC}$ - Left ovary $=3$, Right ovary $=2$, Total 5 impression - Diminished (Low) Antral follicles count 5 .

\section{Treatment}

1. Counselling of the patient and her husband done

2. According to Dosha, Koshtha, Kala and Dosha Avastha, Deepana, Pachana done.

3. Shodhana Chikitsa

4. Shaman Shikitsa

Table 2: Shodhana Chikitsa (From 10/06/2020 till 11/09/2020)

\begin{tabular}{|l|l|l|l|}
\hline Drug & Dose & Duration & Anupana \\
\hline Phalasarpi & $1 \mathrm{tsp}$ & Morning after breakfast & Warm Milk \\
\hline Hingwashtaka churna & $1 \mathrm{gm} \mathrm{BD}$ & Before meal & Warm Water \\
\hline Shatavari Churna with Goghrita & $5 \mathrm{gm} \mathrm{BD}$ & After Breakfast & Warm Milk \\
\hline Manasaitravataka & $1 \mathrm{tab}$ & Before Bed & Normal water \\
\hline
\end{tabular}

Above treatment given for 3 months

Table 3: Shodhana Chikitsa (From 10/06/2020 Till 11/09/2020)

\begin{tabular}{|l|l|l|}
\hline \multicolumn{1}{|l|}{ Basti } & \multicolumn{1}{l|}{ Drug } & Quantity \\
\hline Yog Basti- Sthanik Snehana with Bala Taila and Swedana With Dashamoola Kwatha \\
\hline Anuvasana Basti & Shatapusha Taila & $120 \mathrm{ml}$ \\
\hline Niruha Basti & Mustadi Yapana Basti & $960 \mathrm{ml}$ \\
\hline Uttarabasti & Phalasarpi & $20 \mathrm{ml}$ \\
\hline
\end{tabular}

All 3 Bastis are given on $5^{\text {th }}$ day of menstrual cycle for consecutive 3 cycles.

Follow Up: Monthly Follow Up Taken

\section{Observation and Result}

Ultrasonography and hormonal study was repeated on $3^{\text {rd }}$ day of menstrual cycle in $4^{\text {th }}$ cycle, Transvaginal sonography (6/10/2018) DAY 3 of Menses, LMP 4/10/18, Uterus - AV measuring 7 x 3.4 x 4.4 cm, Endometrial thickness $-5.1 \mathrm{~mm}$, Ovaries and tubes are normal, FSH $-7.83 \mathrm{mlU} / \mathrm{ml}$, AMH $\quad-1.2 \mathrm{ng} / \mathrm{ml}$, $\mathrm{AFC}$-Left ovary $=9$, Right ovary $=5$, Total 14 impression - increased Antral follicles count. Later on, patient came with 1 month 5 days Amenorrhoea on 11/1/19. Urine pregnancy test was positive. Sonography done on 8 March 2019 showed regular gestational sac with 13 weeks and 1 day of gestational age. Placenta anterior, amniotic fluid normal. Patient delivered on 13 September 2019, full term normal delivery with healthy female baby of $2.9 \mathrm{~kg}$.

\section{DISCUSSION}

According to Ayurvedic approach to Dhatukshayajanya Vandhya in terms of diminishing ovarian reserve (DOR) following events takes place.

Nidana Sevana $\rightarrow$ Vata Prakopa $\rightarrow$ Agni Vaishamya $\rightarrow$ Rasa Dushti $\rightarrow$ Artava Dushti $\rightarrow$ Sthana Sanshraya in Garbhashaya $\rightarrow$ Pariksheena of Dhaturupi Artava $\rightarrow$ Dhatukshayajanya Vandhya

\section{Chikitsa is based on following 3 Sutras-}

1) वमनं विरेचनं चैव वस्तिरा(मा)स्थापनं तथा ।

तस्मात्तत् कारयेत स्रीणां प्रसिद्धा: प्रसर(व)न्ति वै ॥ (भे० सं० शा० २)

2) तत्र बस्तिदानं वातरोगोपशमनार्थम्। (तिसटाचार्य)

3) वृद्धिः समानैः सर्वेषां विपरीतैर्विपर्ययः।' (अ.ह.सू. १/१३)

In First Shloka Acharya Bhela states that Shodhana is necessary in Vandhya. Second one is Basti Chikitsa (Enema) is best for aggravated Vata Dosha. Third Shloka states states as similar things increases and opposite of that decreases the output. Ayurveda states the 
holistic remedy which is alternative to hormonal therapy for infertility. Ayurvedic approach to Dhatukshayajanya Vandhya in terms of diminishing ovarian reserve (DOR) is gaining importance. The case presents with Vata Dosha Vikriti (alteration of Dosha) progressing towards Dhatu Kshaya thereby affecting Artava Upadhatu Kshaya Lakshanas ${ }^{[9]}$. The treatment protocol aims for a Shamana of Vata Dosha and correction of Agni thereby creating equilibrium of Doshas in Madhyama Vayavastha (Elderly female). The Dhatupushti itself can be attributed for the physiology of Artava. The oral administration of Hingwashtakachurna has Deepana and Pachana properties. Also, Hingu possess Stripushpajana ${ }^{[10]}$ It also works on Annavahasrotasa which is a main base of any disease through it Agnideepana leads to formation of healthy Ahararasa results in good nutrition to Rasa Dhatu and later on Raja and Stanya Upadhatus. Oral and Internal administration of Phalasarpi owes its Vatahara, Dhatuvardhaka, Vandhyatvahari, Balya and Brimhana properties helps in improvement of Artavakshaya through Dhatupushti thus creating a satisfactory improvement in hormonal assay. Shatavari is a Pushpaprajakari which helps in formation of follicles, ovulation and thereby a healthy progeny. It has Phytoestrogens. Pathogenesis of gynaecological disorders always involves Vata Dosha. तत्र बस्तिदानं वातरोगोपशमनार्थम् । (तिसटाचार्य) Hence Basti Karma (enema) which is the prime treatment modality in Vata Vyadhis ${ }^{[11]}$. It is considered as Ardha Chikitsa ${ }^{[12]}$. Mustadi Yapana Basti ${ }^{[13]}$ is specifically indicated as a superior line of treatment in the condition of Vrishya Karma. Its effect on Anti mullerian hormone (AMH) as well as on FSH etc. thus helps in Balya, Rasayana and Garbhashaya Shodhana Karma. Acharyas says Phalasarpi helps the woman to achieve conception and cures female genital tract disorder. It is Vatahara, Balya, Brimhaniya, Garbhada and Rasayana thus helps in nourishment of reproductive organs and baby later. It works as Prajasthapaka (maintains pregnancy) and Yonipradosha Shamaka (reduces diseases of Uterus and vagina) properties. It also helps in proper development of endometrium, follicles result in healthy progeny. All three Bastis have potency to get absorbed and creates osmotic pressure which enhances absorption of drug administered through intrauterine Uttarbasti. It promotes drug action through endometrium then to internal iliac vein passes into the systemic circulation and exerts its positive action on hypothalamo- pituitary - ovarian axis, which helps in promotion of primordial follicles under control of FSH and regulates function of other hormones. Manasamitravatakam is a Tridosha Shamaka, potent anti-stress, antiolytic and anti-depressant. According Acharya Charaka for Garbhadhana the most important thing is "सौमनस्य गर्भधारणानाम ।" (soundness of mind or peaceful mind). Adding to this not having child gives stress to patient hence added in the prescription.

\section{CONCLUSION}

There are many causes of female infertility but diminishing ovarian reserve is much common cause in elderly patients. The long-term treatments with hormonal imbalance results from many untoward effects like weight gain, stress, depression and premature menopause if not treated well. Ayurveda gives major spotlight on Panchakarma Shodhana as well as Shamana. In this case important consideration was given to Vata Anulomana, Deepana and Pachana because proper functioning of Vata Dosha is necessary in every aspects of fertility means proper functioning of hypothalamopituitary - ovarian axis.

\section{REFERENCES}

1. Fritz Marc A. and Speroff Leon. Clinical Gynecologic Endocrinology and Infertility, 8th edition: Gurgaon; 2011. P 1137.

2. Berek and Novaks Gynecology, Published by Lippincott Williams and Wilkins and Walter Kluwer Business, Page no-1203,1204,1205

3. D. C. Dutta edited by Hiralal Konar, Textbook of Gynaecology, 7th International edition, New Delhi, Jaypee brothers Medical Publishers (P) Ltd., 2016, Ch- 17, Infertility, p-222.

4. D. C. Dutta edited by Hiralal Konar, Textbook of Gynaecology, 7th International edition, New Delhi, Jaypee brothers Medical Publishers (P) Ltd., 2016, Ch- 17, Infertility, p-187. 
5. Sushruta, Dalhana, Shukra Shonitashuddhi, Sushrutasamhita, Shastri KA, Edittion.6, Varanasi, Chaukhambha Sanskrit Sansthan:1985, p - 13

6. Kumari A, Tiwari P V. Yonirogadhikara 1st edition Yogratnakara: Varanasi. Chaukhambha Bharati Academy; 2010:2; p.1139.

7. Artini PG, Ruggiero M, Uccelli A, Obino ME, Cela V (2013) Fertility Management of Patients with Reduced Ovarian Reserve. Reprod Sys Sexual Disorders S5:006. doi:10.4172/2161-038X.S5-006

8. Pandith. Hariprasad tripadi. Haritha samhitha. $4^{\text {th }}$ ed. Varanasi: Chowkhamba Academy: 2015 Page445

9. Acharya YT, editor. 8th ed. Varanasi: Chaukhambha Orientalia; 2005. Susruta Samhita of Acharya Dalhana, Sutra Sthana; p. 70. Ch. 15, Ver. 12.

10. Dravyaguna Vidnyan, Deshpande A.P, Ranade S, Anmol Prakashan, 1st Edition 22nd Oct 2004, Page no 427

11. Vagbhata Krita Ashtang Hridaya, Sarth Vagbhat, Bastividhi Adhyay, 19/87, edited by Dr.Ganesh Krushna Garde, Rajesh Prakashan, Pune, 2012:85.

12. Agnivesa, Dridhabala, Caraka Samhita, Vol.2, Siddhi Sthana, Basti Siddhiradhyaya, 10/4-5, edited by Acharya Vidyadhar Sukla, Prof. Ravi Dutt Tripathi, Chaukhamba Sanskrit Pratishthan, Delhi, 2012:963.

13. Vaidya Jadavaji Trikamaji Acharya, Chraka Samhita, Chakrapanidatta, Chaukhambha surbharati prakashan publication, edition 2008, Siddhi Sthana,12/16, Page no.731

\section{Source of Support: Nil}

\section{Conflict of Interest: None Declared}

How to cite this URL: Divya Pawar \& Sameer Gholap: Ayurved Approach To Diminishing Ovarian Reserve (DOR) In Female Infertility - Case Study. International Ayurvedic Medical Journal \{online\} 2020 \{cited August, 2020\} Available from:

http://www.iamj.in/posts/images/upload/4297 4302.pdf 